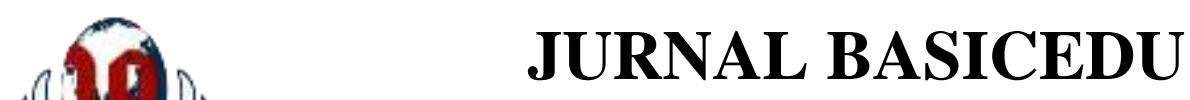

Volume 5 Nomor 6 Tahun 2021 Halaman 5565 - 5572

Research \& Learning in Elementary Education

https://jbasic.org/index.php/basicedu

\title{
Pemanfatan Media Sosial dalam Pembelajaran di masa Pandemi Covid 19
}

\author{
Jenita Anjani Br Sembiring \\ Pendidikan Bahasa Inggris,Universitas Quality Berastagi \\ E-mail: jenitaanjani@gmail.com
}

\begin{abstract}
Abstrak
Kemajuan perkembangan teknologi dapat dirasakan hampir di seluruh lapisan kehidupanmasyarakat. Adapun tujuan penelitian ini yaitu diantaranya melihat seberaa besar pengguna media sosial facebook di kalangan mahasiswa,intensitas mahasiswa dalam menggunakan media sosial facebook serta pemanfaatan media sosial facebook dalam pembelajaran khususnya pada masa pandemi covid-19. Metode penelitian yang digunakan dalam penelitian ini adalah metode penelitian kualitatif, yakni memberikan gambaran pemanfaata media sosial dalam pembelajaran di program studi PGSD Universitas Quality. Pada penelitian ini menggunakan beberapa teknik pengollahan data fiantaranya,dengan studi dokumentasi,wawancara serta menyebarkan angket. Sebagai kesimpulan dari proses penelitian tersebut ditemukan bahwa 94,4\% dari jumlah responden menyatakan bahwa media sosial facebook cukup memberikan manfaat bagi mereka dalam pengerjaan serta pengumpulan tugas,disamping itu terdapat $88,9 \%$ responden yang menggunakan facebook dalam media pembelajaran dimasa pandemi covid-16. Pemanfaatan media sosial facebook merupakan salah satu strategi yang juga cukup efektif dalam pembelajaran daring khususnya pada masa pandemi covid-19 saat ini.
\end{abstract}

Kata Kunci: facebook, Pembelajaran, Mahasiswa.

\begin{abstract}
The progress of technological development can be felt in almost all walks of life of society. The objectives of this research are to see the large number of Facebook social media users among students, the intensity of students in using Facebook social media and the use of Facebook social media in learning, especially during the COVID-19 pandemic. The research method used in this study is a qualitative research method, which provides an overview of the use of social media in learning in the PGSD study program at Quality University. In this study, several data processing techniques were used, including documentation studies, interviews and distributing questionnaires. As a conclusion from the research process, it was found that $94.4 \%$ of the total respondents stated that Facebook social media was quite beneficial for them in working on and collecting assignments, in addition there were 88.9\% of respondents who used Facebook in learning media during the covid-16 pandemic. . The use of Facebook social media is one strategy that is also quite effective in online learning, especially during the current covid-19 pandemic.
\end{abstract}

Keywords: facebook, Learning ,Students.

Copyright (c) 2021 Jenita AnjaniBr Sembiring

Corresponding author :

Email : jenitaanjani@gmail.com

DOI : https://doi.org/10.31004/basicedu.v5i6.1722

ISSN 2580-3735 (Media Cetak)

ISSN 2580-1147 (Media Online)

Jurnal Basicedu Vol 5 No 6 Tahun 2021

p-ISSN 2580-3735 e-ISSN 2580-1147 

Sembiring

DOI: https://doi.org/10.31004/basicedu.v5i6.1722

\section{PENDAHULUAN}

Dalam penelitian sebelumnya memberikan gambaran tentang betapa berpengaruhnya media sosial saat ini dalam kehidupan masyarakat. Mahasiswa saat ini merupakan generasi yang melek internet dan sangat bergantung pada sosial media melalui smartphone yang mereka miliki (A. Setiadi, 2016). Maka dari itu pada saat ini media sosial sendiri bukan sesuatu yang asing di tengah masyarakat. Pemanfaatan media sosial sendiri juga memberikan dampak positif khususnya dalam pembelajaran sendiri.

Perlunya bersikap bijak sana dalam bersikap dan bertindak sudah merupakan sesuatu yang seharusnya dilakukan setiap individu dalam mengelola kehidupan mereka, khususnya bersikap bijak dalam menggunakan media sosial facebook. Penting diketahui bahwa sesungguhnya media sosial facebook saat ini cukup berpengaruh bagi masyarakat. Tidak hanya orang tus, kalangan remaja juga tidak asing dalam menggunakan media sosial yang satu ini. Dalam media sosial ini,umumnya para pemilik akunnya bebas menuangkan ide,pikiran, gagasan mereka akan sesuatu hal yang berhubungan dengan kehidupan mereka pada umumnya.

Pendidikan di era globalisasi sekarang ini membuat manusia dengan mudah mengakses beragam informasi (Kristin, 2016). Jarak dan waktu bukan hambatan yang cukup besar dalam mengakses segala sesuatu.maka dari itu dalam dunia pendidikan terjadi berbagai perubahan yang cukup dinamis dan mengalami perubahan yang begitu besar. Sistem pembelajaran didalam kelas dapat dipindahkan ke dalam bentuk pertemuan di sebuah ruang rapat online,yang mana setiap peserta dapat meghadiri kegiatan tersebut dari kediaman mereka masing-masing secara online. Kondisi saat ini selain dipengaruhi oleh merebaknya wabah penyakit corona, kehidupan manusia pun dipengaruhi oleh perkembangan ilmu pengetahuan dan teknologi yang berdampak pada kemajuan kehidupan manusia dewasa, hal ini juga telah membawa kondisi tersendiri bagi dunia pendidikan (Mintarsih, 2020).

Pendidikan secara umum mempunyai arti suatu proses kehidupan dalam mengembangkan diri tiap individu untuk dapat hidup dan melangsungkan kehidupan (Yayan Alpian, M.Pd., Sri Wulan Anggraeni \& Unika Wiharti., 2019). Pendidikan merupakan dasar dari proses pembentukan pribadi seseorang. Mengingat pendidikan memiliki peran penting dalam pembangunan sebuah bangsa, pemerintah memberi dukungan sepenuhnya demi menunjang proses belajar. Di masa pandemi Covid-19 ini dimana setiap instansi menerapkan protokol kesehatan dimanapun kita berada. Menanggapi protokol pemerintah yang diterapkan, juga berdampak pada dunia pendidikan sendiri. Proses belajar tatap muka dihentikan sementara demi mencegah terjadinya penyebaran virus covid-19.Dampak covid-19 terhadap dunia pendidikan sangat besar dan dirasakan oleh berbagai pihak terutama guru, kepala sekolah, peserta didik dan Orang tua (Santaria, 2020) . Disisi lain kita memahami bahwa proses pendidikan sendiri tidak dapat dihentikan begitu saja. Upaya peningkatan sumberdaya manusia yang berkualitas, bidang pendidikan memegang peranan penting karena pendidikan akan dapat mengembangkan kemampuan serta meningkatkan mutu kehidupan bangsa Indonesia (Dewi, 2018).

Sama halnya dengan Universitas Quality yang mengikuti sepenuhnya aturan pemerintah, proses belajar mengajar secara tatap muka di lingkungan kampus ini juga dihentikan sementara. Namun mengingat proses belajar mengajar tidak dapat dihentikan, pemerintah mengambil kebijakan yakni menerapakn sistem daringn dimana proses belajar mengajar sendiri dialihkan menjadi online.

Pendidikan merupakan suatu proses yang diperlukan untuk mendapatkan keseimbangan dan kesempurnaan dalam perkembangan individu maupun masyarakat. Penekanan pendidikan dibanding dengan pengajaran terletak pada pembentukan kesadaran dan kepribadian individu atau masyarakat di samping transfer ilmu dan keahlian. Dengan proses semacam ini suatu bangsa atau negara dapat mewariskan nilai-nilai keagamaan, kebudayaan, pemikiran dan keahlian kepada generasi berikutnya, sehingga mereka betul-betul siap menyongsong masa depan kehidupan bangsa dan negara yang lebih cerah (Nurkholis, 2013). 


\section{Pemanfatan Media Sosial dalam Pembelajaran di masa Pandemi Covid 19 - Jenita AnjaniBr}

Sembiring

DOI: https://doi.org/10.31004/basicedu.v5i6.1722

Pendidikan juga merupakan sebuah aktifitas yang memiliki maksud atau tujuan tertentu yang diarahkan untuk mengembangkan potensi yang dimiliki manusia baik sebagai manusia ataupun sebagai masyarakat dengan sepenuhnya (Nurkholis, 2013).

Pembelajaran online atau juga sering kita dengar pembelajaran jarak jauh merupakan salah satu kebijakan yang digunakan pemerintah dalam mencegah penyebaran covid-19 di tengah masyarakat. Pembelajaran jarak jauh selalu menggunakan teknologi, mulai dari teknologi yang sederhana sampai teknologi yang terbaru (Natsir et al., 2021).

Keberadaan aplikasi-aplikasi media sosial merupakan salah satu solusi penunjang yang mendukung proses belajar mengajar online di masa pendemi covid-19 saat ini.Berbagai aspek juga mengalami perubahan dari sistem tatap muka secara langsung menjadi sistem virtual. Sama halnya dengan proses pembelajaran sendiri yang terdampak. Penggunaan media sosial sendiri merupakan salah satu caraa yang cukup membantu dalam melanjutkan proses belajar mengajar sendiri. Terjadi perubahan besar-besaran pada aktivitas dan pola hidup masyarakat Indonesia demi mencegah semakin meluasnya pandemi COVID-19 (Damayanthi, 2020).

Menurut (Laughey, 2007; McQuail, 2003) dalam Mulawarman, istilah media sosial tersusun dari dua kata, yakni "media" dan "sosial". "Media" diartikan sebagai alat komunikasi (Laughey, 2007; McQuail, 2003)(Nurfitri, 2017). Sedangkan kata "sosial" diartikan sebagai kenyataan sosial bahwa setiap individu melakukan aksi yang memberikan kontribusi kepada masyarakat. Pernyataan ini menegaskan bahwa pada kenyataannya, media dan semua perangkat lunak merupakan "sosial" atau dalam makna bahwa keduanya merupakan produk dari proses sosial (Durkheim dalam Fuchs, 2014).

Munculnya media sosial seperti facebook sendiri membawa perkembangan di dunia pendidikan. Media sosial sendiri hadir dan mampu mengubah pandangan setiap orang yang menggunakannya. Melalui media sosial sendiri komunikasi tidak lagi dibatasi oleh ruang,waktu dan jarak. Interaksi antara pelajar dan pendidik maupun sebaliknya dapat terhubung kapan saja dengan menggunakan media sosial sebagai salah satu sarana yang digunakan di masa pandemi Covid-19. Media sosial facebook sendiri juga memiliki kelebihan dimana melalui media sosial facebook setiap pelajar maupun guru dapat berkomunikasi dan saling mengekplorasi kelebihan dan menggali bakat yang pada siswa sendiri. Adapun tujuan khusus penelitian ini diantaranya:Melakukan observasi untuk mendeskripsikan penggunaan media sosial di Universitas Quality pada Mahasiswa Program Studi Pendidikan serta melakukan analisis pemanfaatan media sosial dalam proses belajar mengajar di Universitas Quality khususnya pada Mahasiswa Program Studi Pendidikan Guru Sekolah Dasar.

Pada penelitian ini berfokus pada pemanfaatan media sosial facebook dalam pembelajaran dimasa pandemi covid-19 mada mahasiswa programstudi pendidikan dasar Universitas Quality. Dimana diketahui bahwa di masa pandemi covid-19 para mahasiswa diwajibkan mengikuti pembelajaran secara daring. Media sosial facebook merupakan salah satu media sosial yang digunakan para mahasiswa dalam mendukung prose pembelajaran secara daring di masa pandemi covid-19.

\section{METODE}

Penelitian ini merupakan penelitian yang berupa deskriptif. Penelitian deskriptif adalah salah satu jenis penelitian yang tujuannya untuk menyajikan gambaran lengkap / eksplorasi dan klarifikasi mengenai suatu fenomena atau kenyataan sosial. 

Sembiring

DOI: https://doi.org/10.31004/basicedu.v5i6.1722

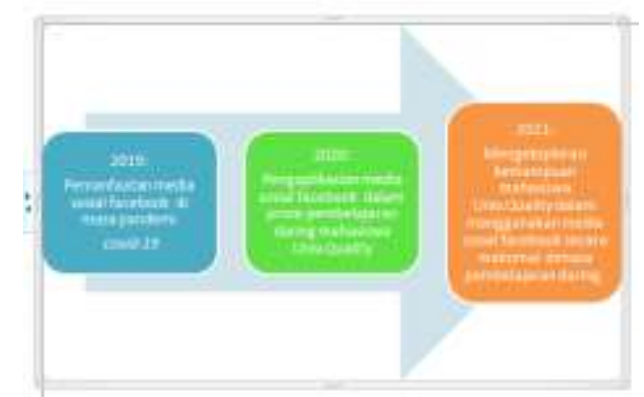

\section{Gambar 1. Roadmap Rencana Penelitian}

Dalam kegiatan penelitian ini, adapun yang diambil sebagai objek penelitian adalah Universitas Quality Program Studi PGSD . Untuk populasi yang dipilih adalah Mahasiswa/i tingkat 3 Kelas A31 Semester Genap Program Studi Pendidikan Guru Sekolah Dasar Universitas Quality, Medan, Sumatera Utara. Untuk waktu penelitian ini akan dilakukan pada bulan Maret pada Tahun 2020.

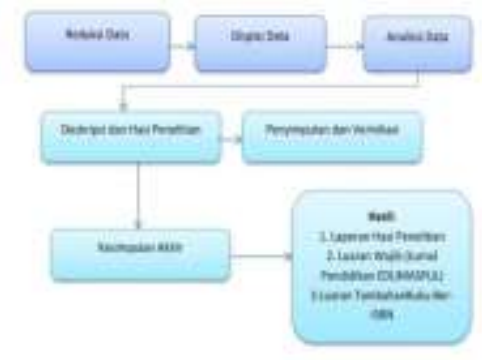

\section{Gambar 2:Diagram Alir Penelitian}

(1) Reduksi Data,berupa data yang telah dikumpulkan ,ditulis berupa laporan terperinci. Laporan ini berfokus pada hal-hal pokok yang cukup penting.(2) Displai Data, dproses ini berupa pengelompokan data yang dilakukan peneliti sesuai dengan rumusan masalah.(3)Analisis Data, merpakan penguraian bentuk penelitian yang dibagi sehingga susunan dan bentuk uraian tersebut terlihat jelas dan maknanya dapat dipahami.(4) Deskripsi hasil penelitian, merupakan pemaparan dan uraian yang tersusun secara sistematis berhasalkan data yang diperoleh di lapangan, dengan tujuan mempermudah orang memahaminya.(5) penyimpulan dan verivikasi,tahap ini merupakan penyimpulan awal yang disempurnakan kembali, yang selanjutnya diverifikasi. (6) Kesimpulan Akhir, Kesimpulan akhir atau final didapatkan setelah pengumpulan data selesai.

Teknik pengumpulan data dalam penelitian kualitatif dilakukan pada natural setting (kondisi alami),sumber data primer dan teknik pengumpulan data lebih banyak pada observasi terus terang atau tersamar, wawancara mendalam (depth interview) dan dokumentasi (Sondak1 et al., 2019).Adapun beberapa teknik pengumpulan data yang digunakan diantaranya yaitu, 1) Angket yang digunakan untuk penelitian ini adalah angket terbuka. Angket terbuka adalah angket yang diberikan kepada siswa dan guru bahasa Inggris yang bertujuan untuk memberikan kesempatan bagi mereka untuk menjawab dengan kalimatnya sendiri (uraian). 2) Selain angket, peneliti juga menggunakan teknik wawancara. Wawancara ini digunakan sebagai teknik pelengkap angket. Wawancara ini diperlukan jika ada informasi yang kurang jelas dari beberapa pertanyaan dalam angket tersebut. Kegiatan wawancara dibagi menjadi 2 yaitu wawancara terstruktur dan tidak terstruktur. Adapun gambaran dari kegiatan ini membahas tentang penggunaan media sosial sebagai penunjang dalam proses pembelajaran pada mahasiswa Program Studi PGSD Universitas Quality. 3) Untuk mendapatkan informasi tentang materi yang dikembangkan, peneliti melakukan pengumpulan informasi berdasarkan kegiatan di lapangan .kegiatan ini berupajenis pengumpulan data yang berpedoman pada 
DOI: https://doi.org/10.31004/basicedu.v5i6.1722

bebrbagai macam dokumen yang berguna untuk menjadi bahan analisis. Klasifikasi dari dokumen ini pun dibagi menjadi 2 yakni dokumen primer dan sekunder. Hasil pelaksanaan penelitian yang telah dicapai adalah analisis data mendeskripsikan pemanfaatan media sosial sendiri dalam pembelajaran di masa pandemi covid19.

\section{HASIL DAN PEMBAHASAN}

\section{Gambaran Umum Lokasi Penelitian}

Universitas Quality merupakan salah satu perguruan tinggi swasta yang berdiri di Sumatera Utara tepatnya di kota Medan yang beralamat di Jl.Ngumban Surbakti No.73. Universitas ini terdiri dari beberapa fakultas,diantaranya fakultas keguruan dan ilmu pendidikan, Fakultas SOSHUM,Fakultas SAINTEK. Salah satu program studi yang paling diminati oleh masyarakat pada perguruan tinggi ini yaitu program studi PGSD yang bergerak di bidang pendidikan. Program studi tersebut terdiri dari beberapa kelas untuk setiap tingkatnya. Adapun visi misi dan tujuan universitas quality sendiri dapat digambarkan sebagai berikut.Misi

Menyelenggarakan dan mengembangkan proses pembelajaran, penelitian dan pengabdian masyarakat yang bermutu dan inovatif dalam bidang IPTEK,membangun suasana Akademis berbasis penguatan sikap intelektual, etika, moral dan kewirausahaan,menyelenggarakan tata kelola yang sehat dan bersih,menyelenggarakan kerjasama dengan berbagai pihak. Tujuan yang dimiliki antara lain,Menghasilkan lulusan yang bermutu, mempunyai sikap intelektual, moral dan etik, serta kewirausahaan bagi pengembangan dan pembaharuan ilmu pengetahuan,menghasilkan karya penelitian yang inovatif dalam peningkatan IPTEK dan memberikan perubahan bagi masyarakat,menghasilkan aktivitas pengabdian pada masyarakat yang mampu menjadi pelopor terwujudnya kesejahteraan masyarakat,mengkaji pengembangan Implementasi pengerahuan teknologi dan seni dengan etika ilmiah, mengembangakan Universitas Quality sebagai Universitas yang sehat dan bersih.

Pada masa pandemic covid-19 saat ini,dalam mewujudkan visi,misi dan tujuan tersebut, proses belajar mengajar yang sebelumnya dilakukan cecara tatap muka (luring), beralih menjadi dalam jaringan (daring). Beragam upaya dilakukan demi terlaksananya proses belajar dan tercapainya visi, misi dan tujuan universitas Quality. Dengan kata lain seluruh proses pembelajaran terlaksana dengan sentuhan teknologi yang cukup memberikan dukungan dalam masa pandemic covid-19 saat ini.

Para pengajar umumnya menggunakan beberapa aplikasi yang dapat mendukung pembelajaran yang disampaikan, salah satunya diantaranya dengan menggunakan media social facebook.

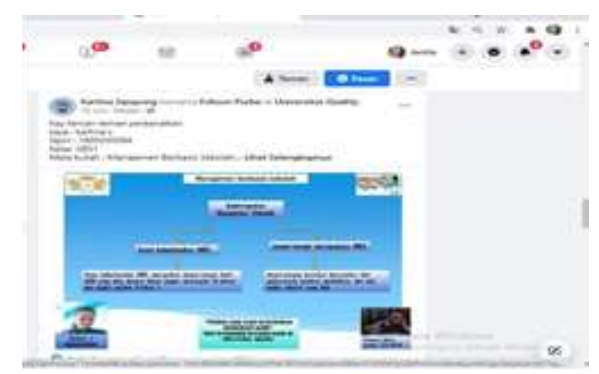

\section{Gambar 3: kreativitas mehasiswa menggunakan facebook}

Media social Facebook dan pembelajaran

Tidak dapat dipungkiri bahwa penggunaan media social yang satu ini cukup memberikan pengaruh besar bagi masyarakat, dimana melalui aplikasi ini semua orang dapat terhubung secara online dan tentu saja dengan aplikasi ini jarak tidak mampu memberi batasan bagi setiap orang untuk berhubungan satu dengan yang lainnya. 

Sembiring

DOI: https://doi.org/10.31004/basicedu.v5i6.1722

Maka dari itu pada masa pandemi ini pengajar memutuskan menggunakan media social sebagai salah satu media social yang mana dosen dan para mahasiswa dapat berinteraksi dalam pembelajaran secara online. Adapun hasil penelitian yang diperoleh dari hasil survey di lapangan akan di gambarkan sebagai berikut.

Adapun jumlah total responden mahasiswa yang diteliti yaitu mahasiswa PGSD kelas A32 yang terdiri dari beberapa mahasiswa. Adapun jenis kelamain para mahasiswa dapat digambarkan pada tabel berikut:

Tabel 1. Jenis Kelamin Mahasiswa

\begin{tabular}{|c|c|c|c|}
\hline No & $\begin{array}{l}\text { Jenis Kelamin } \\
\text { Mahasiswa }\end{array}$ & Jumlah & Persentase \\
\hline & Laki-laki & 6 & $80,6 \%$ \\
\hline & Perempuan & 29 & $19,4 \%$ \\
\hline
\end{tabular}

\section{Gambar 4 : Grafik responden berdasarkan jenis kelamin}

Berdasarkan temuan di lapangan seluruh mahasiswa yang dilakukan survei memiliki akun facebook,dan mereka cendrung dikatagorikan pengguna aktif facebook. Menurut para mahasiswa yang dijadikan sebagai responden,penggunaan facebook tidak semata-mata hanya sebagai hiburan diwaktu senggang. Mereka meyakini facebook juga membantu mereka mendapatkan pengetahuan lain yang berkaitan dengan latar belakang pendidikan mereka. Ditambah lagi dalam masa pandemic covid-19 yang melanda saat ini,dimana seluruh pembelajaran yang sebelumnya dilakukan melalui tatap muka beralih menjadi daring (dalam jaringan). Maka dari ini mahasiswa juga menjelaskan bahwa materi pembelajaran yang mereka dapatkan salah satunya melalui media social facebook sendiri, selain itu menurut para mahasiswa media social tersebut juga cukup membantu mereka melewati pembelajaran dimasa pandemic covid-19. Hal ini dikarenakan mereka juga pernah mendapatkan materi pembelajara yang diberikan pengajar melalui media social facebook sendiri. Adapun gambaran hal tersebut dapat dilihat dari grafik berikut ini.
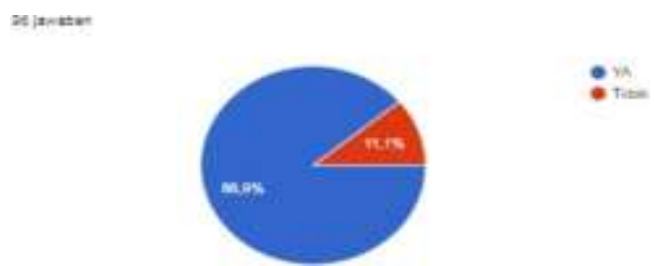

Gambar 5 : Grafik meteri pembelajaran melalui media social facebook

Disamping mendapatkan materi pembelajaran melalui facebook, menurut mahasiswa yang menjadi responden pada penelitian ini, melalui media social sendiri mereka dapat meningkatkan kemampuan mereka khususnya dalam bidang teknologi,yang mana seperti yang dikutahui facebook sendiri memiliki berbagai menu yang memiliki fungsinya masing-masing, selaras dengan pernyataan bahwa pemanfaatan media sosial yang dikelola secara positif tentu akan memberikan dampak positif bagi siswa dalam menggunakan media sosial(Sholekah \& Wahyuni, 2019). Para mahasiswa mengakui bahwa dalam menggunakan facebook mereka dapat memiliki grup-grup yang mana melalui grup tersebut mereka dapat berbagi ilmu pengetahuan yang sesuai dengan latar belakang ilmu mereka. Disamping itu melalui media social sendiri mereka sadar akan 
DOI: https://doi.org/10.31004/basicedu.v5i6.1722

peningkatan mereka dalam mengelola setiap menu yang ada dalam media social tersebut,seperti pengeditan,pembuatan video,grafik serta mereka mampu membuat video kreasi mereka sendiri tanpa mengalami kesulitan yang berarti. Hal tersebut didukung dengan pernyataan mahasiswa yang digambarkan melalui grafik berikut ini.
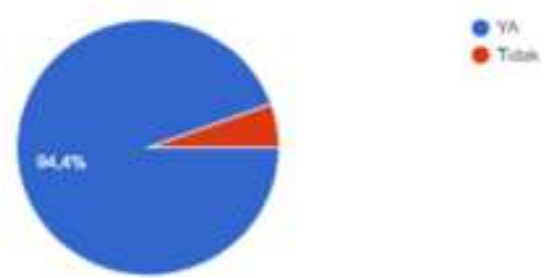

Gambar 6: Grafik kebermanfaatan media social facebook bagi mahasiswa

Menurut pandangan para mahasiswa sebagai responden pada penelitian ini, media sosial facecook memberikan berguna sebagai media pendukung dalam pembelajaran.media sosial facebook sendiri tidak digunakan semata mata sebagai hiburan diwaktu senggang, namun para mahasiswa juga menggunakan media tersebut sebagai sarana pengumpulan tugas serta mempublikasikan kreativitas mereka dengan sentuhan teknologi yang ada dalam media sosial facebook yang mereka miliki.

\section{KESIMPULAN}

Dengan memanfaatkan media sosial khususnya facebook sebagai pendukung proses belajar mampu memberikan pengaruh positif khususnya di masa pandemi covid-19 saat ini. Baik sebagai tenaga pengajar maupun mahasiswa merasakan pemanfaatan media sosial facebook sendiri,dalam mengeksplorasi kemampuan mereka khususnya dalam menggunakan media tersebut dalam mengkreasi tugas maupun materi dalam pembelajaran. Para mahasiswa program studi pendadikan dasar juga memberikan respon positif dalam pemanfaatan media sosial facebook dalam pembelajaran dimasa pandemi covi-19. Pemanfaatan media sosial facebook sendiri memotivasi para mahasiswa untuk semakin maksimal dalam memodifikasi setiap tugas ataupun latihan yang sesuai dengan materi pembelajaran yang diberikan. Mereka juga lebih mengetahui fungsi-fungsi fitur yang digunakan dalam media sosial facebook,sehingga ampu mengeksplorasi ide para mahasiswa.

\section{UCAPAN TERIMA KASIH}

Jika perlu berterima kasih kepada pihak tertentu, misalnya sponsor penelitian, nyatakan dengan jelas dan singkat, hindari pernyataan terima kasih yang berbunga-bunga.Ucapan terimakasih kepada setiap pihak yang mendukung penelitian ini,khususnya kepada Kemenristekdikti Wilayah 1 Sumatera Utara sebagai penyelenggara penelitian ini, serta pihak lainnya yang tidak dapat saya sebut kan satu per satu.

\section{DAFTAR PUSTAKA}

A. Setiadi. (2016). Pemanfaatan Media Sosial Untuk Efektifitas Komunikasi. Jurnal Humaniora.

Arum Wahyuni Purbohastuti. (2017). Vol. 12, No. 2, Oktober 2017. Ekonomika, 12(2), 212-231.

Damayanthi, A. (2020). Efektivitas Pembelajaran Daring Di Masa Pandemi Covid - 19 Pada Perguruan Tinggi Keagamaan Katolik. Jurnal Teknologi Pendidikan, 19(3), 241-262. 
5572 Pemanfatan Media Sosial dalam Pembelajaran di masa Pandemi Covid 19 - Jenita AnjaniBr Sembiring

DOI: https://doi.org/10.31004/basicedu.v5i6.1722

Dewi, W. A. F. (2018). Metode Role Playing Berbantu Media Audio Visual. Jurnal Ilmu Pendidikan, 3, 4146.

Kristin, F. (2016). Efektivitas Model Pembelajaran Kooperatif Tipe Stad Ditinjau Dari Hasil Belajar Ips Siswa Kelas 4 Sd. Pendidikan Dan Kebudayaan, 6, 74-79.

Mintarsih, M. (2020). Pembelajaran Blended Sebagai Strategi Persiapan Kepala Sekolah Menghadapi Era New Normal Di Sdn 3 Putraja- Wa Kecamatan Selaawi Kabupaten Garut. Jurnal Teknologi Pendidikan, 19(3), 337-343.

Natsir, S. R., Sari, E. R., Lestari, A. A., Guru, P., Dasar, S., \& Buton, U. M. (2021). Elementary Education Https://Jbasic.Org/Index.Php/Basicedu. Jurnal Basicedu, 5(6), 5014-5023.

Ngafifi, M., \& Ngafifi, M. (2014). Advances In Technology And Patterns Of Human Life In Socio-Cultural Perspective. Jurnal Pembangunan Pendidikan: Fondasi Dan Aplikasi, 2(3), 33-47.

Nurfitri, A. D. (2017). Perilaku Pengguna Media Sosial Beserta Implikasinya Ditinjau Dari Perspektif Psikologi Sosial Terapan. 25(1), 36-44. Https://Doi.Org/10.22146/Buletinpsikologi.22759

Nurkholis. (2013). Pendidikan Dalam Upaya Memajukan Teknologi Oleh: Nurkholis Doktor Ilmu Pendidikan, Alumnus Universitas Negeri Jakarta Dosen Luar Biasa Jurusan Tarbiyah Stain Purwokerto. 1(1), 24 44.

Nurmala, S., Triwoelandari, R., \& Fahri, M. (2021). Pengembangan Media Articulate Storyline 3 Pada Pembelajaran Ipa Berbasis Stem Untuk Mengembangkan Kreativitas Siswasd/Mi Siti Nurmala $1 \square$, Retno Triwoelandari 2 , Muhammad Fahri 3. Jurnal Basicedu, 5(6), 5024-5034.

Putria1, H., Maula2, L. H., \& Uswatun3, D. A. (2020). Analisis Proses Pembelajaran Dalam Jaringan (Daring) Masa Pandemi Covid-19 Pada Guru Sekolah Dasar. 4(4), 861-872. Https://Doi.Org/10.31004/Basicedu.V4i4.460

Ramli Abdullah. (2016). Lantanida Journal, Vol. 4 No. 1, 2016. Lantanida, 4(1).

Riko1, Lestari2, F. A. P., \& 3, I. D. L. (2020). Penggunaan Media Sosial Sebagai Media Pembelajaran. 3(2), 258-266.

Santaria, R. (2020). Dampak Pandemi Covid-19 Terhadap Proses Pengajaran Bagi Guru Dan Siswa Pendahuluan. 3(2), 289-295.

Setiadi, A. (2014). Pemanfaatan Media Sosial Untuk Efektifitas Komunikasi. Jurnal Ilmiah Matrik, 16(1).

Sondak1, S. H., Taroreh2, R. N., \& Uhing2, Y. (2019). Faktor-Faktor Loyalitas Pegawai Di Dinas Pendidikan Daerah Provinsi Sulawesi Utara. 7(1), 671-680.

Stefanny Grace Natalia ${ }^{1} \square$, F. K. (2021). Efektivitas Penggunaan Media Pembelajaran Google Classroom Sebagai Bentuk Peningkatan Kualitas Hasil Pembelajaran Ips Sekolah Dasar Stefanny Grace Natalia ${ }^{1} \square$, Firosalia Kristin². Jurnal Basicedu, 5(6), 5043-5049.

Triyana, I. G. N. (N.D.). Media Sosial Dalam Proses Pembelajaran. Jurnal Pendidikan Hindu, 79-90.

Yayan Alpian, M.Pd., Sri Wulan Anggraeni, M. P., \& Unika Wiharti., N. M. S. (2019). Pentingnya Pendidikan Bagi Manusia. Jurnal Buana Pengabdian, 1(1), 66-72.

Yogi Yuda Hidayat,Maskur, J. (2019). Pemanfaatan Media Sosial Facebook Sebagai Media Belajar Peserta Didik Pada Mata Pelajaran Ppkn Kelas Viii A . Pendahuluan A . Latar Belakang Masalah Pendidikan Merupakan Sektor Yang Sangat Penting Dalam Menentukan Kualitas Suatu Bangsa . Kegagalan Pendidi. Jtep, 4, 760-771. 